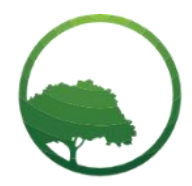

Research in Business \& Social Science

IJRBS VOL 10 NO 6 ISSN: 2147-4478

\title{
Investigating the impact of mobile telecom service characteristics on consumer satisfaction in urban Uganda
}

\author{
Dawz Manyaga ${ }^{(a) *}$ (D) Umit Hacioglu ${ }^{(b)}$ \\ (a) MA., Graduate School of Business, Ibn Haldun University, Istanbul, Turkey \\ (b) Professor, School of Business, Ibn Haldun University, Istanbul, Turkey
}

\author{
A R T I CLE IN F O \\ Article history: \\ Received 12 July 2021 \\ Received in rev. form 18 Aug. 2021 \\ Accepted 20 August 2021 \\ Keywords: \\ Servqual, Service Quality, Customer \\ Satisfaction, Telecom, \\ Telecommunication \\ JEL Classification \\ M30, L96
}

\begin{abstract}
A B S T R A C T
This paper aims to examine the impact of mobile telecom service characteristics on consumer satisfaction in urban Uganda, using a Servqual model. The association between customer satisfaction level and service quality characteristics has been tested with a regression analysis. In this study assurance as a Servqual dimension has been substituted with tariffs to exhibit its effect on customers. satisfaction levels. Findings verified that some of the Servqual dimensions including reliability, empathy, and responsiveness have been positively affecting the customer satisfaction level in the Ugandan context. The study also demonstrated that the prices of products and services of telecom companies were not the major concerns for telecom consumers in Uganda. The study, finally, provides some practical guidelines to managers of telecom companies as well as hinting out which Servqual dimensions are valued most by customers in Uganda.
\end{abstract}

(C) 2021 by the authors. Licensee SSBFNET, Istanbul, Turkey. This article is an open access article distributed under the terms and conditions of the Creative Commons Attribution (CC BY) license (http://creativecommons.org/licenses/by/4.0/).

\section{Introduction}

Developments in communication technologies have become core competencies behind the successful growth strategies of pioneering companies across the globe over the last several decades (Hacioglu \& Aksoy, 2021). Nowadays, the digitalization process of business organizations is closely linked with the communication technologies and social media strategies in the era of Industry 4.0 (Hacioglu \& Sevgilioglu, 2019; Hacioglu, 2019). Therefore, there is a growing interest in generating extra demand by applying marketing strategies integrated with service quality solutions in digital era (Hacioglu, 2020). Naturally, decision makers in business organizations, practitioners and policy makers in telecommunication industry are seeking new ways out of domestic competitions to overcome the threats and obstacles stemming from competitors.

The emergence of technology has reliably contributed to a proliferated access of communication services edging off costs in many parts of the world. With simply a mobile phone, users can now be able to send and receive short message services (SMS), download data, internet access (Ibrahim et al., 2014). Mobile telecommunication service providers currently continue to invest large sums of capital and making extensive research to improve on infrastructure and quality of their service provision (Grigoriou et al., 2018).

Since the paradigm of marketing has shifted from conventional ways of marketing to digital shopping; online purchasing decisions by consumers have forced various companies to tailor services more than they have been practicing with a target of retaining their customers (Vatamanescu et al., 2017). The ability to study consumers' ways of buying products has given telecommunication companies a chance to understand what to offer to markets. However, the contemporary issue within online marketing as criticized by tech giants is security and authentication problems. For years, consumers that are vulnerable to security threats have been compelled to file several lawsuits against major companies. It is profoundly known that customers react to service failures. That isif a company fails to critically think on how to address customers' complaints (Smith et al., 1999). To contain this, companies have

* Corresponding author. ORCID ID: 0000-0003-2497-9762

(C) 2021by the authors. Hosting by SSBFNET. Peer review under responsibility of Center for Strategic Studies in Business and Finance. https://doi.org/10.20525/ijrbs.v10i6.1382 
come up with strategies to combat security fugitives. Nonetheless, even when this is the case, there are still fewer efforts done to stop the ongoing crimes.

The Servqual literature has been present in academics for a while, however, the need to use this literature for a contextual study to address country specific phenomena was not perceived by earlier studies. The need for a contextual study is to address country specific phenomenon's that have not been addressed by various studies in academia. There is also a strong literature linking service quality characteristics in telecommunication service industry with customer satisfaction levels in emerging economies (Hahm et al., 1997; Kim, 2004; Zihayat et al., 2021; Al-Mashrai et al., 2020). Nonetheless, there has not been a sufficient debate on this topic for urban areas of least developing economies.

Telecom companies have been in existence for a long-time enabling people to communicate even within different geographical locations. However, there has been a wide swing in the development and within subscription numbers in this sector for various reasons. Given that this study is driven towards the context of Uganda, it is evident that there have been many telecom companies entering and leaving the country. Customer satisfaction is one of the factors that have placed these companies risk forcing many to either improve or rather prepare for an exit.

The environment of telecom companies in Uganda is quite convincing since the process of licensing has greatly given birth to several companies. The reason for this is the availability of customers and favourable working conditions given to companies has greatly facilitated the number of telecom companies to increase. Even though, customer satisfaction (CS) and service quality (SQ) in Uganda's telecom sector have been studied over the past years by various researchers, there is still a research gap for studies focusing on the rural areas of Uganda. Moreover, there are always outliers in services that drive unsatisfied customers to complain of which the previous studies have not paid attention to.

This paper aims to analyse current practices and research regarding consumer buying behaviour, and to find out whether customers of mobile telecom services in Uganda are satisfied using Servqual model as an assessment tool.

The study used quantitative survey with a sample of 511 respondents from Uganda. Data of this study was collected using an online survey method and analysed with SPSS version 21. Data was then empirically tested using regression modelling technique to test the model. The results from the analysis suggest that Servqual model positively influences customer satisfaction within the context of urban Uganda.

This research is divided into five sections. Firstly, the research will start by diving into the available up-to-date research directed towards the relationship between SQ and CS. Second, the research hypothesis will come in the second place within the study and the available supporting will be presented. Thirdly, a methodology will be employed in the study to help us easily test the presented hypothesis. Fourth, the results of the study will be presented and discussed. Lastly, the conclusion, managerial, and research implications of the research will be presented.

\section{Literature Review}

\section{Theoretical and Conceptual Background}

\section{Understanding Service quality}

There has been a lot of emphasis in the academic investigation to understand SQ. It is contemplated to be a critical determinant of competitive advantage for any organization. It is also notable that all firms compete in service offerings-where offerings act as a communication link between them and customers. Just like quality, there is no general definition of SQ. At a time when SQ was in its infancy, it was defined as the measure between customers' expected and perceived quality (Lewis \& Booms, 1983; Grönroos, 1982; Lehtinen \& Lehtinen 1991) perception and trust.

Products are measured easily by their dimensions of size, color, texture, and so forth. In contrast, it is difficult to measure the quality associated with services. This is because customers' desires transform with new information. It is thus also important to know that having extensive knowledge that can't be applied in product quality is inconsistent in measuring SQ. Customer expectation and perception have contributed to a great debate among researchers to consider the best tool for evaluating SQ. It is thus assumed that managers in manufacturing plants are less likely to perform in service sectors. However, this assumption was re-iterated by (Ghobadian et al., 1994) stating that manufacturing industries consider SQ than product quality. The question arising in literature is whether consumer perception or expectation directly influences SQ.

Cronin \& Taylor (1994) concur with the argument that perceptions affect SQ. In addition, (Page \& Spreng, 2002) in their study also found out that desires which in this case are termed as preference/perceptions directly affected SQ/satisfaction. Perceptions govern buying behaviors of people. Once a customer is not convinced by elements of a product, it is relatively difficult for one to purchase in the future. Roest \& Pieters (1997) defined SQ as a relativistic (not absolute), cognitive evaluation of product performance and experience in a post-purchase stage. Using an example of law firms, it is irrelevant for a customer to hire a low-rated over an overrated firm. However, since the performance of the low-rated firm is less, customers' perceptions of the low-performing firm will always not be satisfied- and thus cannot hire them. 
Using the same example of law firms, it is identifiable that in this case, SQ can only be realized when a case is won. Therefore, SQ becomes difficult to prove (Yap \& Kew, 2007); if organizations cannot understand customers' problems. Since it is not simply quantifiable, measuring it becomes difficult. Consequently, concurrent measurements of experiences and perceptions of SQ are important. Nevertheless, it is not advisable to compare the performance of services based on "public ratings". Customers are treated to be first but might not always be fair. Companies have always been shifted by customer ratings -forcing many to restructure or adopt new ways of conducting business. Regardless of all circumstances, a full diagnostic approach for measuring CS is necessary than relying on public ratings if desired SQ is to be attained.

Services that add no value to customers' eyes are most likely to remain on shelves. It is in the goodwill of firms to offer quality services. However, it is common that there is always a $60 \%$ of work that adds no value to them. Michael George once a CEO at Fortune 500 authored a book titled "lean six sigma". With a combination of two principles lean and Six Sigma, manufacturing firms could speed up their work, reduce overall costs of production, and increase service reliability. SQ can be achieved by easily applying the two nodes in the manufacturing sector.

Lean focuses on maximizing speed, eliminating costs as well as separating value from non-value work in the process cycle. Six Sigma, in contrast, emphasizes more on focusing on what customers prefer, recognizing how variation inhibits the reliability of delivering services as well as providing an infrastructure for obtaining SQ (George, 2003). Nevertheless, research also suggests that services are perceived to be of quality if they are traded with gifts (Darke \& Chung, 2005). For example, if a hotel offers its customers free spa services, those customers will discern it as special and quality.

The revenue growth pressure that stems from competition might overshadow the ability of firms to benefit from cost reduction. Cost reduction can only be met if organizations utilize available technology to gather potential information on market demands (Nitin et al., 2005); develop products and services that subdue competition as well as maintaining SQ. Competition pressures organizations to overreact for available demand and market size. Hence competition also forces organizations to not only focus on processes but also on the way how services are delivered. In other words, with the help of these two (lean and Six Sigma), it is easy to realize returns on invested capital vis-à-vis SQ.

\section{Customer Satisfaction}

Interest in research on CS has invigorated many different interpretations and approaches on what causes satisfaction. CS for a long time has been a central concept in modern marketing practice and thought, emphasizing much on delivering satisfaction (Yi, 1990), and gaining returns at the end of the process. Satisfaction as a concept not only covers customers, it also perhaps attracts producers as well. Nevertheless, it is also important to consider SQ as an influencing factor towards achieving overall satisfaction.

CS is an antecedent of SQ in operations management and service sectors. This argument was however overturned by Cronin \& Taylor (1992) whose empirical results in their study produced the opposite. Recent research suggests that satisfaction is the difference between customers' experience post-purchase comparing it with what was expected (Oliver, 1977,1980; Parasuraman et al, 1985). Specifically, expectations create a frame of reference about which customers make comparative judgments (Oliver, 1980). Outcomes that score less than expected are rated low whereas those with better scores are rated high.

Many believe that CS is largely influenced by how customers' experience with services varies with expectations. In several literatures, SQ might be the only easiest way for measuring satisfaction, however, there are no easiest means of measuring quality. Research focusing on satisfaction rotates around expectancy-disconfirmation. Oliver and DeSarbo (1988) in their study found out that perceived quality and disconfirmation had a strong influence on satisfaction than on expectations. Thus, there is a reason to accept that quality has an invaluable-direct role in determining satisfaction (Eugene \& Mary, 1993).

Consequently, satisfaction and SQ are not only measured but statistically related to market share and customer retention (Rust et al, 1995). Although satisfaction is always subjected to products (tangible goods), its emphasis in this study is shifted towards service because the study is examining the telecom sector. Iacobucci et al. (1995) in assessing the difference between SQ and CS, it was held that satisfaction reflects customers' experiences with that of service.

Another definition by (Davis \& Maggard, 1990) viewed CS as a suitable measure of the cost of having a customer to wait as compared to waiting time in a sense that dissatisfaction or satisfaction as it might be the case, directly has greater impacts on profits on the firm. Operations that take long hours cause dissatisfaction. Consequently, customers of the service sector such as hotels, banks, retail, telecom, often require less processing times to be satisfied. In their study, Davis conducted a linear regression analysis which showed how significantly satisfaction was conversely related to waiting time. Their findings concluded that satisfaction is affected at the time customers wait before entering services (placing orders) than when customers are in the process itself (cashier finishes taking orders). Shorter waiting times had a higher correlation with CS. Given this sequel, managers should always regulate on how and what consequences satisfaction/dissatisfaction with waiting might affect customers' perceptions of the service experience (Hensley \& Sulek, 2007).

User experience varies with how consumers consume products and services. These variations are caused by either demographic or societal factors such as age, gender, and so forth. However, there is no general conclusion on how customers get satisfied. It is rather 
a cognitive behavior embedded within customers. Nevertheless, satisfaction can also be an outcome of customers' learning that a particular brand can satisfy their needs (Tuominen, 1999).

Satisfaction is affected by innumerable contextual variables (Giese \& Cote, 2000). Fornell et al (1996) defined CS as the overall evaluation over time based on total consumption experience. The definition supports the argument in the study carried out by Giese and Cote who identified consumption experience as a component of defining CS. Moreover, satisfaction is not only cognitive but includes affective components. Studies of an affective phenomenon are covered in (West brook \& Oliver, 1991; Westbrook, 1987). This study takes a position that affects is an antecedent to satisfaction and that satisfaction is an outcome from evaluating the effect derived from a consumption experience (Coghlan \& Pearce, 2009).

From a marketing perspective, a brand is only said to be strong if customers can remember its name by default. Affect traces- play an important role in CS evaluation. Emotions during consumption produce high equivocal implications such as memories that individuals may use to infer their overall attitude to products and services. This happens if customers are satisfied; therefore, affect is within its own- a component of post-purchase expression that positively feeds into assessments of satisfaction (Szymanski \& Henard, 2001). However, affect has several setbacks because it considers and deals with basic emotions. It is always worth noting that customers' emotions are indecisive in making rankings, hence CS can be poorly evaluated if an idiosyncratic approach is used by customers.

Satisfaction was defined by Hill et al., as attitudes and feelings that customers normally hold about their experiences within an organization (Hill et al., 2007; Anderson et al., 1994; Fornell, 1992). Attitudes that customers have towards an organization determine the future relationship. It is fantastic to think that organizations do have a special delight way of making customers become attached to their products. Firstly, through recognizing what they want/prefer. Secondly, through monitoring CS with reliable tools to identify gaps that need to be stressed. Attitudes create customer loyalty (CL).

Loyalty is a susceptibility to repurchase from the same firm again (Edvardsson et al, 2000). CL creates a significant relationship between organizations and customers. Nevertheless, enormous benefits of CL lie within a range of retaining existing customers, corporate profitability, and increase in sales, positive word of mouth, as well as increasing market share. In addition, it is worth noting that loyal customers are less costly to serve than new customers (Heskett, 2002). Since it is a contributing factor to financial profitability, organizations are argued to focus all their resources on building customer loyalty. Therefore, satisfaction greatly has an impact on profits and growth of the firm, and indirectly the same applies to loyalty.

Although satisfaction appeals to both tangible and intangible goods, this makes it difficult to be easily assessed. This study however recommends that CS can also be understood with the expectancy-disconfirmation paradigm that was modelled by Oliver (Oliver, 1977,1980). Efforts to rationalize satisfaction and dissatisfaction involve consumers' expectations and perceptions of product performance. Nevertheless, satisfaction was defined by ISO 9000 as customer's perception of the degree to which customer's stated or implied needs or expectations are fulfilled (Hoyle, 2009). As affirmed in Bearden \& Teel (1983), expectations perform functions of adaptation levels defining generally accepted standards at which performance is judged.

Expectations create frames of references about which one makes a comparative judgment (Oliver, 1980), about satisfaction. This view is of no difference to Bearden \& Teel (1983). In contrary to expectations, disconfirmation has been categorized into two, negative and positive disconfirmation. Negative disconfirmation arises when a product performs poorly than expected, and confirmed when performance is as expected as well as positively disconfirmed if performance is better than predicted (Oliver \& DeSarbo, 1988; Oliver, 1977, 1980, 1981; Yi, 1990; Churchill \& Surprenant., 1982). Thus, performance above expectations may not have a bigger impact on the profitability and CS levels. Nevertheless, performance below expectations may be catastrophic (Anderson \& Mittal, 2000). There is a mix in literature as to whether SQ, expectations, and disconfirmation significantly affect CS. There are mixed corroboration conclusions on this subject matter.

A study carried out by Eugene \& Mary (1993) found that satisfaction was positively influenced by perceived quality than expectations. Their study significantly remarked that negative disconfirmation lowered satisfaction. Another study by Churchill \& Surprenant (1982) also found that perceived quality preferably than expectations directly influences satisfaction for durables.

\section{Empirical Review and Hypothesis Development}

The theoretical model is adopted by a study conducted by Zeithaml, Parasuraman and Berry (1988). The reason for choosing variables of service quality-is because they are believed to affect customer satisfaction within telecommunication services. The model proposes that service quality consists of reliability, tangibles, empathy, assurance, responsiveness that are assumed to be having a direct effect on customer satisfaction. Our Servqual dimensions are placed to be independent variables, while customer satisfaction is presented as the dependent variable as well as age, gender, level of education as controlling variables. Nevertheless, since Assurance does not appeal to fit within the region where research is carried out, the researcher, therefore, decided to replace it with tariffs.

\section{Reliability}

In short, reliability can be framed as the ability to always deliver the expected standards, handling customers' problems within a minimal time, and maintaining error-free records. Parasuraman et al. (1985, 1988, 1994) ascertained that reliability means 
organizations accurately perform services. In addition, Ennew et al. (2013) conceptualized reliability as the ability to dependently perform services, accurately and the ability to treat problems faced by customers. On the other hand, reliability is similar to consistency. Consistency refers to the compatibility and uniformity between things and parts. Frei et al. (1999) suggest that SQ needs to include uniformity of service output around an ideal target value which is determined by customers. In the case of telecommunication, a strong network connection together with its availability at all times is a significant measure to increase and maintain the reputation of an organization. Hence it was hypothesized that:

$H_{I}$ : Reliability positively influences customer satisfaction in the telecom sector of urban Uganda.

\section{Empathy}

Empathy means providing individualized attention to customers. It is believed by (Parasuraman et al, 1994) as the special attention given to customers, caring, and providing services to customers. Empathy is believed to be inborn and cannot be taught. It increases customers loyalty that arises from the good behavior employees extend towards customers. Empathic employees are said to identify customers' needs better and can tailor personal interactive behaviours to customers they give value to/ specific customers (Giacobbe et al. 2006). Furthermore, it is believed that higher levels of satisfaction can easily result in workplaces because empathy increases employees' understanding of customers (Homburg, Wieseke, and Bornemann 2009).

In a developing world, customers have requirements and demands that vary day by day, it is the companies' duty to meet the demands of customers. Once their demands are not met, they are obliged to search for other suppliers. Based on the above relevance of empathy in measuring CS, I put forward the following hypothesis:

$\mathrm{H}_{2}$ : Empathy positively influences customer satisfaction in the telecom sector of urban Uganda.

\section{Responsiveness}

Responsiveness is referred to as the ability to respond to customers' requests timely and flexibly. Responsiveness also consists of partners understanding themselves in such a way that they understand and support each other as well as fulfilling important personal needs and goals. It also captures the ability to customize the service to customer needs and the notion of flexibility within customer service. The importance of this dimension is undeniable. In a study by Parasuraman et al. (1990), responsiveness was the second important attribute behind reliability. Therefore, from the present relevance of responsiveness, it is then hypothesized that:

$H_{3}$ : Responsiveness positively influences customer satisfaction in the telecommunication sector of Uganda.

\section{Tangibility}

Generally, tangible assets are man-made physical components and materials (Sureshchandar et al, 2002). Parasuraman also described tangible dimensions as physical quality such as equipment, facilities as well as personal appearance (Parasuraman et al., 1988). In the telecommunication industry, tangibles like Simcard packets, the interior design of telecom network shops are one of the most important elements that entice customers to enter shop halls to purchase services. For this reason, tangibility should always be modified to fit within the perception and expectations of customers. Because of this, I hypothesize that:

\section{$H_{4}$ : Tangibility positively influences customer satisfaction in the telecommunication sector of Uganda.}

\section{Tariffs}

Tariffs in this case are prices charged for different sets of services provided by telecom companies. Customers become price sensitive if they find it easy to evaluate products and services. Moreover, the price evaluation process will always match with customers' perceptions of the services. Where product A falls short of a customer's perception, tariff evaluation might become tight. However, tariffs should always match the consumption goals of customers. For example, heavy purchasers of telecom services tend to present a low-price sensitivity than low buyers. A study by (Leinsle et al, 2018) found that customers usually judge tariffs basing on price fairness and transparency of the firm. Because of this, I hypothesize that:

H5: Tariffs positively influences customer satisfaction in the telecommunication sector of Uganda.

\section{Conceptual Framework}

Using SERQUAL model, figure 1 represents a model showing effects of service quality dimensions on customer satisfaction. The dimensions used here to assess the relationship between customer satisfaction and service quality are reliability, tangibility, empathy, assurance, and responsibility. 


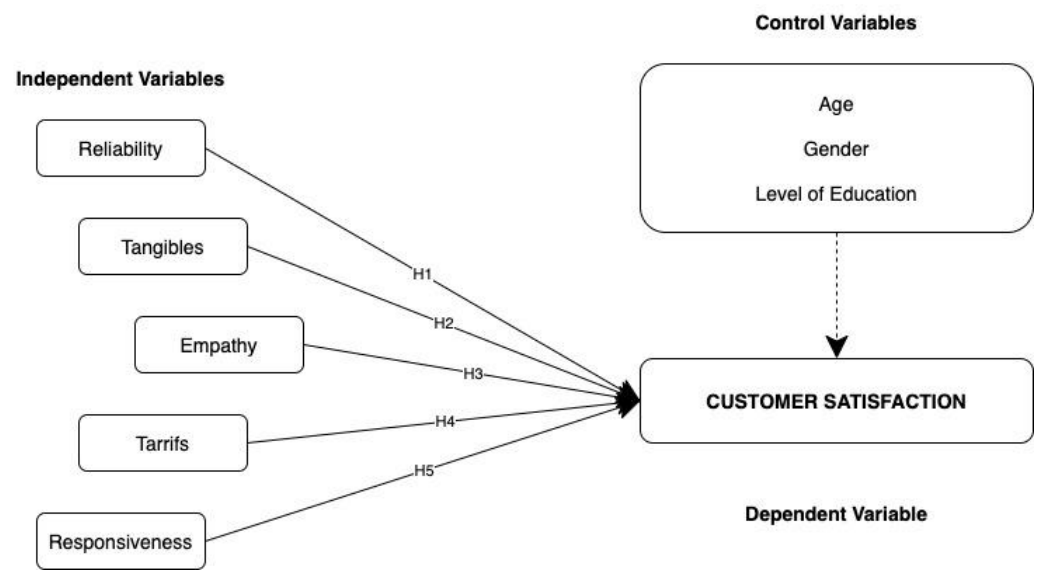

Figure 1: Research Model

\section{Research \& Methodology}

This study assesses the relationship between dimensions of service quality and customer satisfaction. As mentioned in the overall study, these dimensions are reliability, tangibility, empathy, assurance, and responsibility, respectively. This part provides methods and procedures that the researcher proposed to use in the study. The section consists of data and method, sampling design, data collection instruments, validity and reliability of the research instrument, method of data analysis.

\section{Data}

The target population of this study consisted of customers (middle and upper class) of different telecom companies located in urban Uganda. The population of residents living in Kampala which is the base of the study is about 3,469,510 according to World population review website. Out if this population, only those above 15 years which were the least age within age of below 18 shall and will be eligible for this study. The reason for targeting urban areas in Uganda is because of the access of telecommunication services that the population have, and the fact that it is where the majority of people have access to mobile phones. The other greater reason for targeting population aged 15 (18 and above) is that it is assumed that these groups of people are likely to participate and freely engage in the study without any influence.

To meet the goal of this research, a survey method was adopted to collect opinions/data using online google forms from respondents. The reason for collecting data using online google forms is because the study was carried out within a pandemic period that could not allow the author to easily access data on the ground. The design was expected to yield analysable data that would identify the factors, which could be tested quantitatively. Furthermore, the study sought to provide information that would form the basis for recommendations for practice. A self-administered questionnaire was used to obtain respondents data. The data collection tool consisted of both closed and open-ended questions in line with the research questions. The questionnaire also consisted of SERVQUAL dimensions (Reliability, Responsiveness, Tangibles, Assurance, and Empathy) subdivided into 24 statements, which were directed to measuring service quality in urban Uganda. The first part provides information related to demographic dimensions of respondents such as age, marital status, and gender. The second part provides information of telecom companies that respondents are subscribed to, the number of years they have so far spent using the operator's line. The next step provides information related to perceptions of customers towards service quality in urban Uganda.

The model of the present study was used as a guide for the structured questionnaire because it provides an in depth understanding of full information of research questions in which it tries to describe how customers perceive quality of services in urban Uganda and in reality, while also measuring their customer satisfaction levels.

\section{Measures}

The present research has been conducted basing on primary data that was collected from participants in Uganda. A questionnaire was developed with four questions on every variable. A Likert scale was used giving freedom to participants to select from Agree, Strongly Agree, Neutral, Strongly Disagree, and disagree respectively. The questionnaire starts with addressing the main purpose of the study to participants as well as outlining the title of the study. Nevertheless, to keep information private, all participants were assured of their data privacy and that it would be kept confidential.

\section{Sample}

There are different ways of carrying out sampling not limited to stratified, simple random, and random sampling. This study however decided to adopt random sampling because it is the most reliable and expensive method of collecting data (Hurlburt, 1979). Sampling 
also allows a researcher to collect data for a long period without influencing respondents' results. In addition, using this method helps to reduce the influence of uncontrolled factors in research (Emerson, 2015). The advantage of collecting data individually is that the operation of theoretical constructs, research design, and data collection assures coherence and makes the data useful in solving underlying problems (Hox \& Boeije, 2005). A self-administered questionnaire was used to obtain data from 511 respondents within the central region of Uganda (Kampala) who actively consumed telecommunication services from companies such as Uganda Telecom, MTN, Airtel, and Africell and so forth.

\section{Validity and Reliability}

Reliability refers to the extent to which studies can/ are replicated (LeCompte \& Goetz, 1982). İt is important for measurements to be precise and reliable to enable other researchers to use the same instrument or measurement. In fact, Sanders et al. (2009) hinted that researchers should be able to get results that are consistent (but not a must) if the same measure is to be employed within studies. For internal consistency to be determined (Heale \& Twycross, 2015), the most used test is Cronbach's alpha ( $\alpha$ ), and it presents interrelation of a set of items constituting a scale. Numerical values as stipulated by Cronbach's alpha range from 0 to 1 . Results with values next to 1 present high reliability of the scale where as vice versa is true. Generally, for a better reliability, (Cronbach, 1951) recommends values not be less than 0.70 . İn addition, it has also been recently emphasized that a value of 0.60 can act as a lower threshold given that it can be acceptable for studies involving the use of newly developed measures such as the ones in this study.

\section{Analysis and Findings}

Data from 511 respondents was run using SPSS (V21) to extract results. Results from the analysis report that ages between 23-24 had the highest number of respondents with $39.7 \%$, followed by those within the age of $18-22$ with $27.8 \%$. $15 \%$ of the respondents were aged 46 and above while $16.8 \%$ was aged below 18 years. Out of the total respondents, $58.9 \%$ were men compared to $41.1 \%$ who represented women. Level of education was dominated with respondents attaining undergraduate followed by master students and lastly, high school students.

\section{Inter-item correlation}

An inter-item correlation was carried out using Pearson correlation test to find out the existence of any relationship between independent variables excluding controlling variables. The findings show that tangibility had the highest relationship with tariffs, $r$ (0.786; $\mathrm{P}<0.01)$. Whereas the relationship between tangibility and reliability followed with $\mathrm{r}(0.619 ; \mathrm{P}<0.01)$. The results further proved that variables namely reliability and tariffs also had a strong relationship, $\mathrm{r}(0.602 ; \mathrm{P}<0.01)$

Table 1: Inter-item correlation

\begin{tabular}{lllllll}
\hline & Tangibility & Empathy & Tarrifs & Reliability & Satisfaction & Responsiveness \\
\hline Tangibility & 1.000 & .466 & .786 & .619 & .480 & .543 \\
\hline Empathy & .466 & 1.000 & .521 & .343 & .597 & .482 \\
\hline Tariffs & .786 & .521 & 1.000 & .602 & .490 & .531 \\
\hline Reliability & .619 & .343 & .602 & 1.000 & .452 & .531 \\
\hline Satisfaction & .480 & .597 & .490 & .452 & 1.000 & .466 \\
\hline Responsiveness & .543 & .482 & .531 & .531 & .466 & 1.000 \\
\hline
\end{tabular}

Source: Author

\section{Case Processing Summary}

The table below presents the sum of respondents who filled the questionnaire online. Since no value was excluded from the analysis, we expect that respondents prompted/ attended to all the available questions and that no question was left unanswered.

Table 2: Case processing summary

\begin{tabular}{llll}
\hline & & $\mathbf{N}$ & $\mathbf{\%}$ \\
\hline Cases & Valid & 511 & 100.0 \\
\hline & Excluded $^{\mathrm{a}}$ & 0 & .0 \\
\hline Total & 511 & 100.0 \\
\hline
\end{tabular}

Source: Author, 2021

Reliability statistics

Table 3: Reliability Statistics

\begin{tabular}{lll}
\hline Reliability Statistics & & \\
\hline Cronbach's Alpha & $\begin{array}{l}\text { Cronbach's Alpha Based on Standardized } \\
\text { Items }\end{array}$ & N of Items \\
\hline $\mathbf{8 0 6}$ & .716 & 9 \\
\hline
\end{tabular}

Source: Author, 2021 
The results from reliability analysis in table 2 above clearly indicate a high level of internal consistency of the scale. This is well explained by the value of Cronbach alpha which is 0.806 .

\section{Correlation}

Correlation intends to assess the strength of association between two variables. Correlations in this study were statistically significant at 0.05 and 0.01 , respectively. In the table, controlling variables are categorized as age, gender, and highest level of education.

Highest level of education was found to be correlated with empathy (0.109), reliability (-0.131), and satisfaction (-0.104). It slightly negatively correlated with reliability $(-0.131)$. Ugandans who have studied within higher institutions of education prefer to choose telecom companies that solve their problems without interaction. Furthermore, there is a chance for learned people to choose telecom companies that are available 24 hours a day in case if a customer encounters a problem.

Empathy and tangibility are correlated with a coefficient of 0.466 . This means that the more empathetic the telecom company is towards customers, the more they would make their showrooms and infrastructure to look better so as they attract more customers. Correlation between tariffs and tangibility, as well as empathy. Tariffs has a positive correlation coefficient of 0.786 with tangibility. The increase in tariffs for different telecom services accounts for an improvement in companies' infrastructure and tangible components such as top-up cards for credit on mobile phones.

Results in the table above also present correlation between reliability and other variables of tangibility, empathy, and tariffs. The level of reliability is highly attributed to the level of sophisticated technology that companies have. For a call centre to be reliable, there should be a reliable network and data for online communication. Responsiveness is positively correlated with tangibility ( 0.543$)$, empathy (0.482), tariffs (0.531), reliability (0.531), and satisfaction (0.466). Customers prefer telecom companies that are responsive to their inquiries. The more responsive the customer support centre are, the more empathy and reliable they are assumed to be by customers, hence the more satisfied they become.

Table 4: Correlation

\begin{tabular}{|c|c|c|c|c|c|c|c|c|c|}
\hline & 1 & 2 & 3 & 4 & 5 & 6 & 7 & 8 & 9 \\
\hline Age (1) & 1 & & & & & & & & \\
\hline Gender (2) & .030 & 1 & & & & & & & \\
\hline Hlo education (3) & .072 & .065 & 1 & & & & & & \\
\hline Tangibility (4) & -.057 & .033 & .018 & 1 & & & & & \\
\hline Empathy (5) & -.038 & .043 & $.109 *$ & $.466 * *$ & 1 & & & & \\
\hline Tarrifs (6) & -.042 & .005 & .031 & $.786 * *$ & $.521 * *$ & 1 & & & \\
\hline Reliability (7) & -.016 & .025 & $-131 * *$ & $.619 * *$ & $.343 * *$ & $.602 * *$ & 1 & & \\
\hline Satisfaction (8) & -.035 & -004 & $-104 *$ & $.480 * *$ & $.597 * *$ & $.490 * *$ & $.452 * *$ & 1 & \\
\hline Responsiveness (9) & -.041 & -005 & .013 & $.543 * *$ & $.482 * *$ & $.531 * *$ & $531 * *$ & $466 * *$ & 1 \\
\hline
\end{tabular}

* Correlation is significant at the 0.05 level (2-tailed)

** Correlation is significant at the 0.01 level (2-tailed)

Source: Author, 2021

Table 5: Model Summary

\begin{tabular}{|c|c|c|c|c|c|c|c|c|}
\hline \multicolumn{9}{|c|}{ Model Summary } \\
\hline \multirow[t]{2}{*}{ Model } & \multirow[t]{2}{*}{$\mathrm{R}$} & \multirow[t]{2}{*}{ R Square } & \multirow{2}{*}{$\begin{array}{l}\text { Adjusted } \\
\text { Square }\end{array}$} & \multirow[t]{2}{*}{$\mathrm{R}$} & \multirow{2}{*}{$\begin{array}{l}\text { Std. Error of the } \\
\text { Estimate }\end{array}$} & \multicolumn{3}{|l|}{ Change Statistics } \\
\hline & & & & & & R Square Change & F Change & df1 \\
\hline 1 & $.678^{\mathrm{a}}$ & .460 & .452 & & 2.18547 & .460 & 53.527 & 8 \\
\hline
\end{tabular}

\begin{tabular}{lll}
\hline Model Summary & \\
\hline \multirow{2}{*}{ Model } & Change Statistics \\
\cline { 2 - 3 } & df2 & Sig. F Change \\
\hline $\mathbf{1}$ & 502 & .000 \\
\hline
\end{tabular}

a. Predictors: (Constant), Responsiveness, Gender, Age, Highest level of education attained, Empathy, Reliability, Tangibility, Tariffs.

Source: Author, 2021

The overall model fit represents correlation between observed as well as predicted customer satisfaction value which is .678. $\mathrm{R}$ squared as shown refers to the proportion of variance in the dependent variable (customer satisfaction) which is predicted from independent variables which in this study are categorized as age, gender, highest level of education, tangibility, responsiveness, empathy, tariffs, and reliability. R squared is also known as the coefficient of determination. 
As indicated in the table above, $46 \%$ of variance in satisfaction can be predicted from independent variables. This technically means that $46 \%$ of customer satisfaction is predicted from level of independent variables. However, these results measure overall strength of the association and do not reflect the extent to which any independent variable is associated with the dependent variable. To understand this, check table 5 below.

Table 6: Model summary using Durbin-Watson

\begin{tabular}{llllll}
\hline \multicolumn{2}{l}{ Model Summary } & & & \\
\hline Model & R & R Square & Adjusted R Square & $\begin{array}{l}\text { Std. Error of the } \\
\text { Estimate }\end{array}$ & Durbin-Watson \\
\hline $\mathbf{1}$ & $.678^{\mathrm{a}}$ & .460 & .452 & 2.18547 & 1.705 \\
\hline
\end{tabular}

Source: Author, 2021

The independence of observations is checked by examining for independence of errors using the Durbin-Watson test. Durbin-Watson test also tests for autocorrelation in the data set. Autocorrelation can be useful for technical analysis which is mostly concerned with the relationships of different data more especially in the marketing environments. The value of Durbin-Watson test ranges in values from 0 to 4 . A value from 0 and less than 2 means that there is a positive autocorrelation and values from 2 to 4 indicate a negative autocorrelation. Considering our model, the Durbin-Watson test is lesser than 2 indicating a positive autocorrelation within the sample.

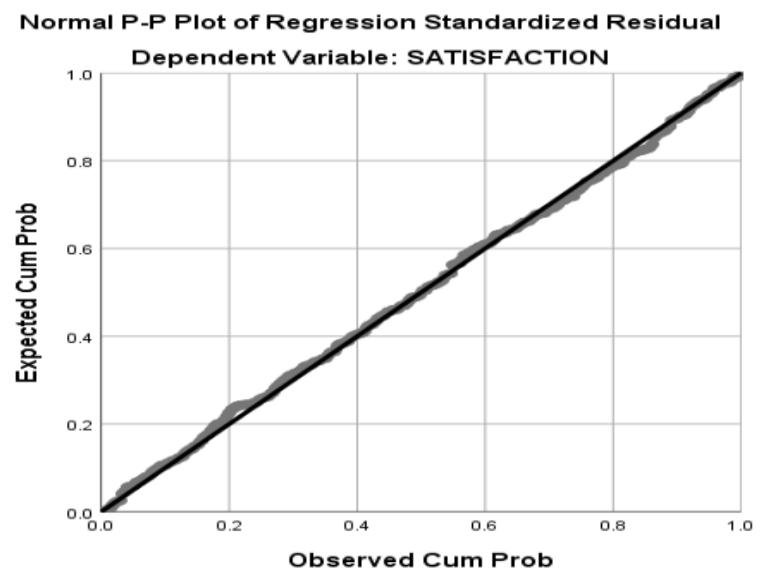

Figure 2: Normal P-P Plot of regression Standardized Residual; Source: Author, 2021

In statistics, a normal probability-plot is a probability plot for assessing how closely two sets of data agree. It can be used as a graphical adjunct to a test of a fit of probability distribution (Michael, 1983). It's clearly known that the P-P plots two cumulative distribution functions (cdf's) against each other. Normally, range from 0 to 1 . The comparison line in the analysis is the $45^{\circ}$ line that has ranges of from $(0,0)$ to $(1,1)$. The distributions are said to be equal if and only if the plot falls on the line. Thus, any deviation indicates a difference between the distribution (Derrick et al., 2016) or non-normality. The dots of our plot are along the 45-degree line. So, since they lie within the degree line, we have a normality of residuals.

\section{ANOVA}

One should remember that ANOVA, regression, and T-test are all part of the general linear model. So, the results in the table above are also another way that we can look at our linear model. The table tells us that the model with several predictors works better than simply predicting using the mean. The significance value .000 in the table means that using independent variables as our predictor is better than not using independent predictor in the model. Nevertheless, the ANOVA table simply tells us that the model works. See below to the regression- coefficients explanation to find out how the model works.

Table 7: Anova

\begin{tabular}{lllllll}
\hline \multicolumn{1}{l}{ ANOVA $^{\mathbf{a}}$} & & & & & \\
\hline Model & & Sum of Squares & df & Mean Square & F & Sig. \\
\hline \multirow{2}{*}{$\mathbf{n}$} & Regression & 2045.291 & 8 & 255.661 & 53.527 & $.000^{\mathrm{b}}$ \\
\cline { 2 - 7 } & Residual & 2397.691 & 502 & 4.776 & & \\
\cline { 2 - 7 } & Total & 4442.982 & 510 & & \\
\hline
\end{tabular}

a. Dependent Variable: Satisfaction

b. Predictors: (Constant), Responsiveness, Gender, Age, Highest level of education attained, Empathy, Reliability, Tangibility, Tariffs.

Source: Author, 2021 
Table 8: Coefficients

\begin{tabular}{|c|c|c|c|c|c|c|}
\hline \multicolumn{7}{|c|}{ Coefficients $^{\mathrm{a}}$} \\
\hline \multicolumn{2}{|c|}{ Model } & \multicolumn{2}{|c|}{ Unstandardized Coefficients } & \multirow{2}{*}{$\begin{array}{l}\text { Standardized } \\
\text { Coefficients } \\
\text { Beta }\end{array}$} & \multirow[t]{2}{*}{$\mathbf{t}$} & \multirow[t]{2}{*}{ Sig. } \\
\hline & & B & Std. Error & & & \\
\hline \multirow[t]{9}{*}{1} & (Constant) & 4.884 & .708 & & 6.896 & .000 \\
\hline & Age & .021 & .103 & .007 & .209 & .835 \\
\hline & Gender & -.125 & .198 & -.021 & -.632 & .528 \\
\hline & $\begin{array}{l}\text { Highest level of education } \\
\text { attained }\end{array}$ & -.454 & .111 & -.138 & -4.092 & .000 \\
\hline & Tangibility & .083 & .049 & .095 & 1.680 & .094 \\
\hline & Empathy & .346 & .031 & .446 & 11.023 & .000 \\
\hline & Tarrifs & .045 & .050 & .051 & .901 & .368 \\
\hline & Reliability & .126 & .041 & .138 & 3.038 & .003 \\
\hline & Responsiveness & .083 & .035 & .101 & 2.343 & .020 \\
\hline
\end{tabular}

Source: Author, 2021

While ANOVA tells us whether our model works well, we are yet to find out how the model works. This table tells us how the individual predictor variables contribute to the model. First, there are two types of coefficients in the table, and this is unstandardized and standardized. We have the B values that help us to create our regression equation. Additionally, there is also something interesting about T-test scores. If it is not significant, then it means that predictor variables do not add to a model, and if that is the case, we ignore it and the vice versa is true. When we carefully investigate our model, there are predictors with significant levels of statistics.

A bivariate regression was conducted to examine how well (independent variables) such as Age, gender, highest level of education, tangibility, responsiveness, empathy, tariffs, and reliability could predict the level of customer satisfaction. It was conducted to systematically test the hypothesis. Table 20 presents structured results for the full sample. A scatter plot showed that the association between our independent variables as well as customer satisfaction was negative linear and did not reveal any bivariate outliers. Correlation between our independent variable and customer satisfaction was statistically significant, $r(502)=.678, P<.001$ (look back to our regression model summary).

The regression equation for predicting customer satisfaction from our independent variables was $y=4.9+.021-.125-.454+$ $.083+.346+.045+.126+.083+e$.

The $R^{2}$ for this equation was .460 ; that is $46 \%$ of the variance in customer satisfaction was predictable from the level of independent variables.

Table 9: Collinearity Diagnosis

\section{Collinearity Diagnostics ${ }^{\mathrm{a}}$}

Model

Eigenvalue Condition Index $\quad$ Variance Proportions

(Constant) Age Gender Highest level of education

attained

1

\begin{tabular}{|c|c|c|c|c|c|c|}
\hline 1 & 8.535 & 1.000 & .00 & .00 & .00 & .00 \\
\hline 2 & .143 & 7.730 & .00 & .39 & .05 & .09 \\
\hline 3 & .110 & 8.810 & .00 & .43 & .40 & .14 \\
\hline 4 & .102 & 9.156 & .00 & .03 & .41 & .57 \\
\hline 5 & .038 & 14.964 & .00 & .01 & .00 & .03 \\
\hline 6 & .028 & 17.511 & .01 & .01 & .00 & .00 \\
\hline 7 & .020 & 20.687 & .29 & .08 & .08 & .01 \\
\hline 8 & .015 & 24.106 & .70 & .05 & .05 & .15 \\
\hline 9 & .010 & 28.925 & .00 & .00 & .00 & .00 \\
\hline
\end{tabular}

Source: Author, 2021

The collinearity diagnosis table shows different sets of data. The importance of collinearity diagnosis is to confirm whether there are problems with multicollinearity. In our table above, the program in this case SPSS tries to extract uncorrelated dimensions from the predictor data of the model and if there happens to be no multi-collinearity problems, then all dimensions must contribute something meaningful to the variance of the predictor data set. İn addition, where we have multicollinearity, then one of more of the dimensions become redundant. 
Eigen values as shown above in the table are from vector analysis. It is a standard rule that dimensions with a high Eigen value show a large independent contribution to the data and dimensions with a very low eigen value indicate a problem. And because they are a problem, they do not contribute anything meaningful to the data which is assigned for multicollinearity. Looking at results from the table above, dimension 2-9 are all having no problem. However, it is not always simple to interpret results with eigen values because they at times depend on the number of predictors in the model.

The next column is the condition index. Condition indices are computed as the square roots of the ratios of the largest eigenvalue to each successive eigenvalue (IBM, n.d.). A rule of thumb is held that values greater than 15 indicate a multicollinearity possible problem and values greater than 30 a greater sign of a problem. In our table, four \{dimension 6,7,8, and 9\} of the indices are larger than 15 , suggesting a possible multi-collinearity problem.

The next is to consider regression co-efficient decomposition matrix. Here, for each regression coefficient, variance is distributed to different eigen values. There are no dimensions that are linearly dependent because there isn't any dimension having a variance proportion greater than 90 .

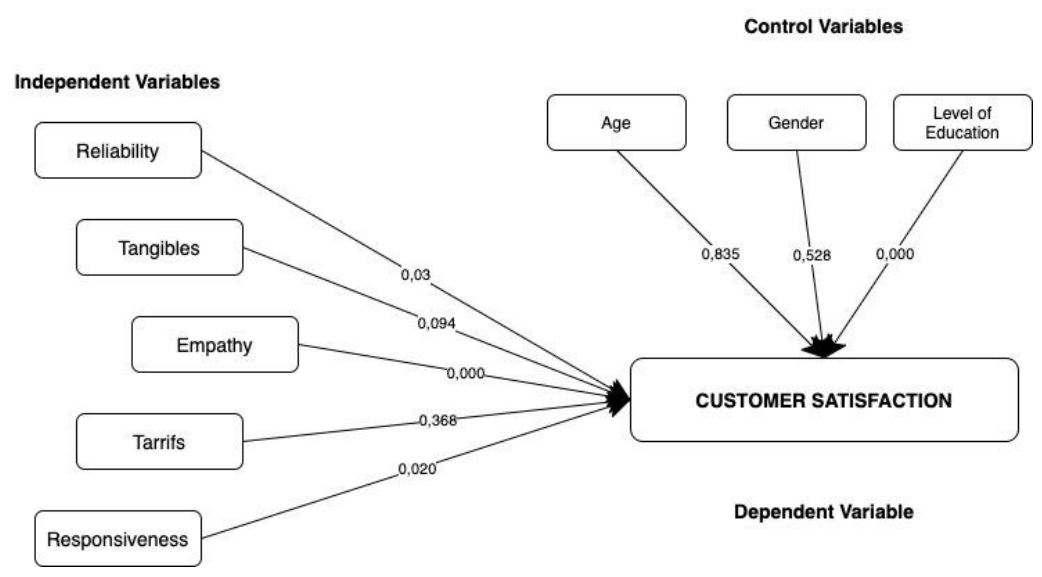

Figure 3: Regression -coefficients analysis results

Table 10: Structural results for hypothesis

\begin{tabular}{llll}
\hline Dimension & Path & Significance & Hypothesis \\
\hline Reliability & CS & .003 & Supported \\
\hline Tangibility & CS & .094 & Not supported \\
\hline Empathy & CS & .000 & Supported \\
\hline Tariffs & CS & .368 & Not supported \\
\hline Responsiveness & CS & .020 & Supported \\
\hline
\end{tabular}

$\mathrm{H} 1$ is fully supported meaning that reliability has a significant influence on customer satisfaction.

$\mathrm{H} 2$ is not supported meaning that tangibility does not significantly influence customer satisfaction in the Ugandan context.

H3 is supported denoting that empathy significantly influences customer satisfaction.

H4 is not supported meaning that tariffs do not influence customer satisfaction according to this study.

$\mathrm{H} 5$ is fully supported explaining that responsiveness of telecommunication companies largely influences customer satisfaction.

\section{Conclusion}

The general findings of the study suggest that service quality dimensions influence customer satisfaction. Additionally, the study concludes that if one of the dimensions of service quality are handled with a high level of seriousness, then customer satisfaction is believed to increase with time. Along with the effect of service quality dimensions on consumer satisfaction, theoretical development also hypothesized that control variables of age, gender, and highest level of education of respondent's impact customer satisfaction. The study decided to employ tariffs instead of assurance- to measure its influence on customer satisfaction given its role of influencing peoples' behaviours in selecting process.

Although this is the case, findings did not find any significant influence of tariffs on customer satisfaction, sending an indicator to service providers that customers in Uganda are less concerned about prices. Nevertheless, results suggest that dimensions of reliability, which refers to the probability of a firm to perform its intended service dependably and accurately for a specific period, and the dimension of responsiveness, which is the ability to provide quality services at a higher speed as well as empathy rank highly 
in terms of influencing customer satisfaction. These results are consistent with those of Parasuraman et al (1990), Loke et al (2011), as well as Homburg et al (2009), who found out that responsiveness, reliability, and empathy were ranked higher when examining SERVQUAL dimensions.

This study has identified several important implications that need service managers to take note of. Firstly, employees of telecommunication companies must adopt empathic behaviours during employee-customer interactions. Employees are one of the internal customers and the first stake holders of an organisation. This directly affects their way of operation because empathetic behaviours they portray have a direct impact on brand awareness and the same effect on loyalty. It should be noted that this study identified that empathy significantly influences CS. Thus, employees are supposed to be trained on how to show empathetic behaviours to create a pro-customer image at workplace. Once this is installed, customer loyalty increases, the number of customer increases, as well as employee's behaviour being overhauled.

Secondly, service reliability should be put in place to secure existing customers as well as attracting new ones. Strategies that outline the importance of reliability should be made. This can be through making sure that connectivity is made available throughout the whole geographical areas of Uganda. Uganda is well known to have low connectivity especially in areas outside Kampala. Perhaps reliability of telecom companies entirely depends on how they establish their services accessible to everybody in different areas. This should then be followed by employing employees with the right skills to promptly attend to customers problems as soon as possible. Managers should therefore avoid employing employees with low interpersonal skills who cannot easily identify problems in rush conditions.

Thirdly, the results of this study confirmed the importance of responsiveness. The most important element in a business is to be able to respond to a challenge in a quick manner. Once this is not present, then there is no reason for making negotiations. For a better service, managers should always consider hiring employees who can easily identify customers problems. Customer care personnel who attend to phone calls always have a gift of understanding callers' problems that need to be fixed. And the same applies to customers, their intention to call support centres is to seek for solutions not explanations. Therefore, managers should think to integrate process restructuring to clearly figure out recurring problems so that they are attended to.

The main difference between this study and other studies is that our analysis did not measure the gap that exists between expectations and customers perceptions while measuring the influence between customer satisfaction and service quality. Instead, the present study measured how individual dimensions of service quality influence customer satisfaction basing on the responses provided by respondents. This is the first limitation of the study. Therefore, for anyone interested in measuring the impact of service quality on customer satisfaction, measuring the gap between respondents' expectations and perceptions of different services should be considered.

The number of respondents is another factor to consider while carrying out research. It should also be noted that the sample size of 511 is quite low to consider given the total number of customers living within urban places of central Uganda. Research that involves many participants is highly preferred to research with low number of participants. In fact, low participants lead to data generalizations. Therefore, further research should focus more on surveying more people by using measures to gather data and more measures centred towards objectives to lessen the number of self-reporting bias.

Moreover, this study particularly focused on only urban areas found in the central region of Uganda to investigate the impact of telecom service characteristics on consumer satisfaction. The major aim of concentrating only in urban areas is partly because major telecom service activities happen in these specific areas than in other rural areas. However, still this amounts to a greater portion of failure because it ignored the importance of other regions which is not acceptable while carrying out research.

Assurance is said to be one of the best dimensions incorporated in SERVQUAL model to measure CS. This study did not list assurance in the model, instead it incorporated tariffs to find out what people think about and to evaluate its influence on customer satisfaction. Thus, future studies should incorporate assurance to fully examine its effect on CS in telecom sector of Uganda.

\section{Acknowledgement}

This study has been developed based on the Fawz Manyaga's MA Thesis supervised by Prof.Dr. Ümit Hacioglu at Graduate School of Business, Ibn Haldun University, Istanbul, Turkey.

\section{References}

Al-Mashraie, M., Chung, S. H., \& Jeon, H. W. (2020). Customer switching behavior analysis in the telecommunication industry via push-pull-mooring framework: A machine learning approach. Computers \& Industrial Engineering, 144, 106476. https://doi.org/10.1016/j.cie.2020.106476

Anderson, E. W., \& Mittal, V. (2000). Strengthening the satisfaction-profit chain. Journal of Service research, 3(2), 107-120.

Anderson, E. W., Fornell, C., \& Lehmann, D. R. (1994). Customer satisfaction, market share, and profitability: Findings from Sweden. Journal of marketing, 58(3), 53-66. https://doi.org/10.1177/002224299405800304

Bearden, W. O., \& Teel, J. E. (1983). Selected determinants of consumer satisfaction and complaint reports. Journal of marketing Research, 20(1), 21-28. https://doi.org/10.1177/002224378302000103 
Churchill Jr, G. A., \& Surprenant, C. (1982). An investigation into the determinants of customer satisfaction. Journal of marketing research, 19(4), 491-504. https://doi.org/10.1177/002224378201900410

Coghlan, A., \& Pearce, P. (2009). Tracking affective components of satisfaction. Tourism and Hospitality Research, 10(1), $42-58$. https://doi.org/10.1057/thr.2009.18

Cronbach, L. J. (1951). Coefficient alpha and the internal structure of tests. psychometrika, 16(3), 297-334.

Cronin Jr, J. J., \& Taylor, S. A. (1994). SERVPERF versus SERVQUAL: Reconciling performance-based and perceptions-minusexpectations measurement of service quality. Journal of marketing, 58(1), 125-131. https://doi.org/10.1177\%2F002224299405800110

Darke, P. R., \& Chung, C. M. (2005). Effects of pricing and promotion on consumer perceptions: it depends on how you frame it. Journal of Retailing, 81(1), 35-47. https://doi.org/10.1016/j.jretai.2005.01.002

Davis, M. M., \& Maggard, M. J. (1990). An analysis of customer satisfaction with waiting times in a two-stage service process. Journal of Operations Management, 9(3), 324-334. https://doi.org/10.1016/0272-6963(90)90158-A

Derrick, B., Toher, D., \& White, P. (2016). Why Welchs test is Type I error robust. The Quantitative Methods for Psychology. 12 (1): 30-38. https://doi.org/10.20982/tqmp.12.1.p030

Edvardsson, B., Johnson, M. D., Gustafsson, A., \& Strandvik, T. (2000). The effects of satisfaction and loyalty on profits and growth: products versus services. Total quality management, 11(7), 917-927.

Emerson, R. W. (2015). Convenience sampling, random sampling, and snowball sampling: How does sampling affect the validity of research?. Journal of Visual Impairment \& Blindness, 109(2), 164-168. https://doi.org/10.1177\%2F0145482X1510900215

Ennew, C.; Waite, N.; Waite, R. Financial Services Marketing: An International Guide to Principles and Practice; Routledge: London, UK, 2013; ISBN 978-0-415-52167-3

Eugene W. Anderson, Mary W. Sullivan, (1993) The Antecedents and Consequences of Customer Satisfaction for Firms. Marketing Science 12(2), 125-143. https://doi.org/10.1287/mksc.12.2.125

Fornell, C. (1992). A national customer satisfaction barometer: The Swedish experience. Journal of marketing, 56(1), 6-21. https://doi.org/10.1177/002224299205600103

Fornell, C., Johnson, M. D., Anderson, E. W., Cha, J., \& Bryant, B. E. (1996). The American customer satisfaction index: nature, purpose, and findings. Journal of marketing, 60(4), 7-18.

Frei, F. X., Kalakota, R., Leone, A. J., \& Marx, L. M. (1999). Process variation as a determinant of bank performance: evidence from the retail banking study. Management Science, 45(9), 1210-1220

George, M. L. (2003). Lean Six Sigma for service: How to use Lean Speed and Six Sigma Quality to improve services and transactions. $1^{\text {st }}$ edition. McGraw-Hill, New York, 400.

Ghobadian, A., Speller, S., \& Jones, M. (1994). Service quality. International journal of quality \& reliability management. 11(9), 43-66. https://doi.org/10.1108/02656719410074297

Giacobbe, R. W., Jackson Jr, D. W., Crosby, L. A., \& Bridges, C. M. (2006). A contingency approach to adaptive selling behavior and sales performance: Selling situations and salesperson characteristics. Journal of personal selling \& sales management, 26(2), 115-142. https://doi.org/10.2753/PSS0885-3134260202

Giese, J. L., \& Cote, J. A. (2000). Defining consumer satisfaction. Academy of marketing science review, 1(1), 1-22.

Grigoriou, N., Majumdar, A., \& Lie, L. (2018). Drivers of Brand Switching Behavior in Mobile Telecommunications. Athens J. Mass Media Commun, 7-28.

Grönroos, C. (1982), Strategic Management and Marketing in the Service Sector, Marketing Science Institute, 135

Hacioglu, U. (2020). Digital business strategies in blockchain ecosystems. Springer International Publishing, https://doi.org/10.1007/978-3-030-29739-8

Hacioglu, U. (Ed.). (2019). Handbook of research on strategic fit and design in business ecosystems. IGI Global.

Hacioglu, U., \& Aksoy, T. (Eds.). (2021). Financial Ecosystem and Strategy in the Digital Era: Global Approaches and New Opportunities.

Hacioglu, U., \& Sevgilioglu, G. (2019). The evolving role of automated systems and its cyber-security issue for global business operations in Industry 4.0. International Journal of Business Ecosystem \&Amp; Strategy (2687-2293), 1(1), 01-11. https://doi.org/10.36096/ijbes.v1i1.105

Hahm, J., Chu, W., \& Yoon, J. W. (1997). A strategic approach to customer satisfaction in the telecommunication service market. Computers \& industrial engineering, 33(3-4), 825-828. https://doi.org/10.1016/S0360-8352(97)00258-1

Heale, R.; Twycross, A. (2015). Validity and reliability in quantitative studies. Evidence-Based Nursing, 18(3), 6667. https://doi.org/10.1136/eb-2015-102129

Hensley, R. L and Sulek, J. (2007). Customer satisfaction with waits in multi-stage services. Managing Service Quality: An international Journal, 17(2), 152-173. https://doi.org/10.1108/09604520710735173

Heskett, J.L. (2002), Beyond customer loyalty, Managing Service Quality: An International Journal, 12 (6), $355-$ 357. https://doi.org/10.1108/09604520210451830

Hill, N., Roche, G., \& Allen, R. (2007). Customer satisfaction: the customer experience through the customer's eyes. The Leadership Factor.

Homburg, C., Wieseke, J., \& Bornemann, T. (2009). Implementing the marketing concept at the employee-customer interface: the role of customer need knowledge. Journal of marketing, 73(4), 64-81. https://psycnet.apa.org/doi/10.1509/jmkg.73.4.64 
Hox, J. J., \& Boeije, H. R. (2005). Data collection, primary versus secondary. In Encyclopodia of Social Measurement Amsterdam: Elsevier. https://doi.org/10.1016/B0-12-369398-5/00041-4

Hoyle, D. (2009). ISO 9000 Quality Systems Handbook: Using the standards as a framework for business improvement. Routledge.

Hurlburt, R. T. (1979). Random sampling of cognitions and behavior. Journal of Research in Personality, 13(1), $103-111$. https://doi.org/10.1016/0092-6566(79)90045-X

Iacobucci, D., Ostrom, A., \& Grayson, K. (1995). Distinguishing service quality and customer satisfaction: the voice of the consumer. Journal of consumer psychology, 4(3), 277-303.

IBM (n.d.). Collinearity diagnostics. Retrieved March 24, 2021, from Collinearity diagnostics (ibm.com)

Ibrahim, M., Shahid, M. K., \& Ahmed, S. F. (2014). The impact of telecom services characteristics on consumer for use in Pakistan. Advances in Economics and Business, 2(4), 172-179.

Kim, M. K., Park, M. C., \& Jeong, D. H. (2004). The effects of customer satisfaction and switching barrier on customer loyalty in Korean mobile telecommunication services. Telecommunications policy, 28(2), 145-159. https://doi.org/10.1016/j.telpol.2003.12.003

LeCompte, M. D.; Goetz, J. P. (2020). Problems of Reliability and Validity in Ethnographic Research. Review of Educational Research, 52(1), 31-60. https://doi.org/10.3102/00346543052001031

Lehtinen, U., \& Lehtinen, J. R. (1991). Two Approaches to Service Quality Dimensions. The Service Industries Journal, 11(3), 287303. https://doi.org/10.1080/02642069100000047

Leinsle, P., Totzek, D., and Schumann. J. H. (2018). How price fairness and fit affect customer tarrif evaluations. Journal of Service Management, 29(4), 745-764. https://doi.org/10.1108/JOSM-10-2017-0270

Lewis, R. C., \& Booms, B. H. (1983). The marketing aspects of service quality. Emerging perspectives on services marketing, 65(4), 99-107.

Loke, S. P., Taiwo, A. A., Salim, H. M., Downe, A. G., \& Petronas, U. T. (2011). Service quality and customer satisfaction in a telecommunication service provider. In International conference on financial management and economics, (2), 23-29).

Michael, J. R. (1983). The stabilized probability plot. Biometrika, 70(1), 11-17. https://doi.org/10.1093/biomet/70.1.11

Nitin Seth, S.G. Deshmukh, Prem Vrat, (2005) Service quality models: a review, International Journal of Quality \& Reliability Management, 22(9), 913-949, https://doi.org/10.1108/02656710510625211

Oliver, R. L. (1977). Effect of expectation and disconfirmation on postexposure product evaluations: An alternative interpretation. Journal of applied psychology, 62(4), 480. https://doi.org/10.1037/0021-9010.62.4.480

Oliver, R. L. (1977). Effect of expectation and disconfirmation on postexposure product evaluations: An alternative interpretation. Journal of applied psychology, 62(4), 480. https://doi.org/10.1037/0021-9010.62.4.480

Oliver, R. L. (1980). A cognitive model of the antecedents and consequences of satisfaction decisions. Journal of marketing research, 17(4), 460-469. https://doi.org/10.1177/002224378001700405

Oliver, R. L. (1981). Measurement and evaluation of satisfaction processes in retail settings. Journal of Retailing, 57(3), 25-48.

Oliver, R. L., \& DeSarbo, W. S. (1988). Response determinants in satisfaction judgments. Journal of consumer research, 14(4), 495507. https://doi.org/10.1086/209131

Page Jr, T. J., \& Spreng, R. A. (2002). Difference scores versus direct effects in service quality measurement. Journal of service research, 4(3), 184-192. https://doi.org/10.1177\%2F1094670502004003002

Parasuraman, A., Berry, L. L., \& Zeithaml, V. A. (1990). Guidelines for Conducting Service Quality Research. Marketing Research, 2(4).

Parasuraman, A., Zeithaml, V. A., \& Berry, L. L. (1985). A conceptual model of service quality and its implications for future research. Journal of marketing, 49(4), 41-50.

Parasuraman, A., Zeithaml, V. A., \& Berry, L. L. (1988). Servqual: A multiple-item scale for measuring consumer perc. Journal of retailing, 64(1), 12.

Parasuraman, A., Zeithaml, V. A., \& Berry, L. L. (1994). Reassessment of expectations as a comparison standard in measuring service quality: implications for further research. Journal of marketing, 58(1), 111-124.

Roest, H \& Pieters, R. (1997), The nomological net of perceived service quality, International Journal of service Industry Management, 8(4), 336-351. https://doi.org/10.1108/09564239710174408

Rust, R. T., Zahorik, A. J., \& Keiningham, T. L. (1995). Return on quality (ROQ): Making service quality financially accountable. Journal of marketing, 59(2), 58-70. https://doi.org/10.1177/002224299505900205

Saunders, M., Lewis, P., \& Thornhill, A. (2009). Research methods for business students. Pearson education.

Smith, A. K., Bolton, R. N., \& Wagner, J. (1999). A model of customer satisfaction with service encounters involving failure and recovery. Journal of marketing research, 36(3), 356-372.

Sureshchandar, G.S., Rajendran, C. and Anantharaman, R.N. (2002), "Determinants of customer-perceived service quality: a confirmatory factor analysis approach", Journal of $\quad$ Services $\quad$ Marketing, $16 \quad$ (1), 934. https://doi.org/10.1108/08876040210419398

Szymanski, D. M., \& Henard, D. H. (2001). Customer satisfaction: A meta-analysis of the empirical evidence. Journal of the academy of marketing science, 29(1), 16. https://doi.org/10.1177/0092070301291002

Tuominen, P. (1999). Managing brand equity. Lta, 1(99), 65-100. 
Vatamanescu, E. M., Nistoreanu, B. G., \& Mitan, A. (2017). Competition and consumer behavior in the context of the digital economy. Amfiteatru Economic, 19(45), 354.

Westbrook, R. A. (1987). Product/consumption-based affective responses and postpurchase processes. Journal of marketing research, 24(3), 258-270.

Westbrook, R. A., \& Oliver, R. L. (1991). The dimensionality of consumption emotion patterns and consumer satisfaction. Journal of consumer research, 18(1), 84-91.

Yap, S. F., \& Kew, M. L. (2007). Service quality and customer satisfaction: antecedents of customer's re-patronage intentions. Sunway Academic Journal, 4, 59-73.

Yi, Y. (1990). A critical review of consumer satisfaction. Review of marketing, 4(1), 68-123.

Zihayat, M., Ayanso, A., Davoudi, H., Kargar, M., \& Mengesha, N. (2021). Leveraging non-respondent data in customer satisfaction modeling. Journal of Business Research, 135, 112-126. https://doi.org/10.1016/j.jbusres.2021.06.006

Publisher's Note: SSBFNET stays neutral with regard to jurisdictional claims in published maps and institutional affiliations.

\section{(c) (1)}

(C) 2021 by the authors. Licensee SSBFNET, Istanbul, Turkey. This article is an open access article distributed under the terms and conditions of the Creative Commons Attribution (CC BY) license (http://creativecommons.org/licenses/by/4.0/).

International Journal of Research in Business and Social Science (2147-4478) by SSBFNET is licensed under a Creative Commons Attribution 4.0 International License. 